\title{
Design and Performance of an Innovative Hybrid Constructed Wetland for Sustainable Pig Slurry Treatment in Small Farms
}

OPEN ACCESS

Edited by:

Efthalia Chatzisymeon,

University of Edinburgh,

United Kingdom

Reviewed by:

Brandon Kyle Winfrey,

Monash University, Australia

Maria Elisa Magri,

Federal University of Santa Catarina,

Brazil

${ }^{*}$ Correspondence:

Antonina Torrens

antoninatorrens@ub.edu

Specialty section:

This article was submitted to

Water and Wastewater Management,

a section of the journal

Frontiers in Environmental Science

Received: 23 July 2020

Accepted: 31 December 2020

Published: 12 February 2021

Citation:

Torrens $A$, Folch $M$ and Salgot $M$

(2021) Design and Performance of an

Innovative Hybrid Constructed

Wetland for Sustainable Pig Slurry

Treatment in Small Farms.

Front. Environ. Sci. 8:577186.

doi: 10.3389/fenvs.2020.577186

\begin{abstract}
Antonina Torrens $^{1,2,3 *}$, Montserrat Folch ${ }^{1,3}$ and Miquel Salgot ${ }^{1,3}$
${ }^{1}$ Environmental Health and Soil Sciences Unit, Department of Biology, Healthcare and Environment, Faculty of Pharmacy and Food Sciences, University of Barcelona, Barcelona, Spain, ${ }^{2}$ Nature-based Solutions for Sustainable Development Area, Solidarity Foundation University of Barcelona, University of Barcelona, Barcelona, Spain, ${ }^{3}$ Hidrosec Research Group, University of Barcelona, Barcelona, Spain
\end{abstract}

Simple and suitable treatment of swine slurry from small farms is paramount especially in sensitive areas. This paper evaluates the viability of an innovative nature-based technology hybrid system (a Vertical Flow Constructed Wetland followed by a Horizontal Flow Constructed Wetland both planted with reeds - Phragmites australis) to treat swine slurry for further land application or discharge in water bodies with reduced nitrogen impact. Physicochemical parameters, bacterial indicators, surface deposits and biomass inside the filters were monitored. The hybrid configuration offered a dual function for simultaneous solid-liquid separation and biological treatment. Removal of organic matter and suspended solids was very high ( $>80 \%$ for SS and $>75 \%$ for $\mathrm{COD}$ and $\mathrm{BOD}_{5}$ ) while the overall nitrogen load removal was $65 \%$, due to the combined nitrification/denitrification processes, thus effectively reducing swine slurry nitrogen content. The influence of temperature and design and operational parameters on the treatment efficiency and the hydraulic behavior were also studied. The vertical constructed wetland achieved good hydraulic performance with no clogging problems, despite high pollutant loads. Some of the pollutants were retained and mineralized in the surface deposit layer, increasing around $20 \mathrm{~cm}$ each year. This organic biosolid layer improved filtration efficiency. The high ammonia contents interfered with the growth of Phragmites australis, while the high concentration of suspended solids and organic matter determine the operation and design to be implemented.

Keywords: constrcucted wetlands, hybrid systems, pig slurry, nature-based solutions, pig livestock farming, nitrogen

\section{INTRODUCTION}

Agro-food activities, especially intensive livestock farming can produce high-strength wastewater with marked seasonal fluctuations in terms of quantity and quality. The composition of swine slurry varies greatly, although its component of main concern is nitrogen. Especially, untreated swine slurry contains considerable amounts of non-stabilized organic matter and high concentrations of ammonium that can reach values of $8 \mathrm{~g} / \mathrm{L}$, depending on the farm characteristics (Torrens, 2016). Spreading excess slurry over croplands may result in pollution, mainly by nitrates, of 
groundwater and eutrophication of surface waters also due to phosphorous contents (Armengol and Salgot, 2011). Swine slurry nutrients in excess of crop uptake can accumulate in soils, reaching an oversaturation of nitrates which afterward infiltrate and percolate. At saturation, nutrients are lost to either surface or ground waters (Martinez et al., 2009).

In many areas of Europe, disposal of swine slurry is a serious problem for farmers. In many cases, the harmful environmental effects of pig farm effluents are caused by the high concentration of animals in a limited area and the defective management of the wastes produced. Through the "Nitrate Directive" (91/676/EEC), the EU seeks to reduce water pollution caused or generated by nitrates from agricultural sources. The Directive imposes on the EC Member States the identification of sensitive zones in those countries where action plans must be adopted to reduce nitrate leaching, either to surface water or groundwater. The sensitive areas are those zones where special measures may be given to protect the natural habitats which present a high level of vulnerability. In these territories a maximum of $170 \mathrm{~kg}$ of $\mathrm{N}$ from animal wastes per hectare per year is allowed.

Large swine slurry volumes are currently generated throughout the world. In 2019 Spain has surpassed Germany as the leading pork producer in the EU. The latest data provided by the Spanish Ministry of Agriculture's statistics service estimates pork production in 2019 at 4.627 .179 tonnes, an increase of $2.13 \%$ over 2018 . By autonomous communities, Catalonia was the largest producer of pork, with a total of 1.89 million tonnes. Catalonia's region pig density reaches more than seven heads per hectare, with a total of almost eight million heads (Statistical Institute of Catalonia, 2020), equivalent to an annual production of over 1,000 tons of meat. In vulnerable areas, applying discharge limits, 1 hectare of land can accommodate a maximum of about 50 heads' slurry. In areas of intensive production, the number of heads sometimes exceeds 1,000 per hectare of available land. In such circumstances, there is a surplus of manure, whose application to agriculture is not possible without pre-treatment. The pig industry in many regions of the Mediterranean, including Catalonia, is partially based on hundreds of small farmers, whose limited production and low annual budgets do not allow for implementation of advanced technological waste treatment. This high number of small or medium size piggeries has created the need for a simple, suitable waste disposal technology capable of reducing the nitrogen load applied to land. Small industries, as well as small towns, encounter problems when choosing treatment plant methods that have similar fixed costs regardless of population size and the industry they serve. The high concentration of $\mathrm{N}$ in slurry makes treatment costs too high and sometimes limits the sector's development (Vidal et al., 2018).

Building alternative storage and treatment units or additions to traditional treatment and operational methods is required to abide by the Nitrates Directive (Henkens and van Keulen, 2001). Swine slurry treatment is intended largely to solve this overproduction of nutrients in order to adjust the amount and quality to farmers' demand for organic matter and fertilizer. Swine slurry management usually consists of three main phases. The first-one is the solid-liquid separation, the primary treatment process used to improve liquid manure handling properties and to generate solids. Several methods are available to separate solids from liquids, including sedimentation, mechanical separation, evaporation ponds, dehydration, coagulation and flocculation (Borin et al., 2013). The second phase is converting the solid fraction into an exportable product used for composting or generating biogas. The last phase is usually the reduction of nutrient contents in the liquid fraction to meet discharge criteria or spreading the remaining nutrients on arable land. Nutrient contents reduction in the liquid fraction can be achieved by different techniques: anaerobic codigestion, activated sludge treatment, batch sequencing reactors, ultrafiltration, reverse osmosis or natural technologies such as CWs (Borin et al., 2013). Technically complex systems to reduce nitrogen are not viable at the small and medium scale owing to installation and maintenance (Torrens, 2015).

The lack of solutions for sustainable and cost-effective treatment of agro-industrial wastewater in small-medium farms is a widespread problem. Therefore, there is a need for low energy consumption technologies like nature based technologies easy for the farmer to manage and maintain, and having low construction, operation and maintenance costs. Nature Based Technologies for wastewater treatment use natural, commonly occurring self-treatment processes that take place in soil, water and wetland environments (Torrens, 2015). These technologies (like ponds, constructed wetlands or infiltration-percolation systems) are being used nowadays as a solution for wastewater treatment from different sources (including swine). Constructed wetlands (CWs) have been in use for about 30 years as a sustainable option for treating domestic and urban wastewater. Although they are mainly used for this purpose, CWs are starting to be adopted as nature-based solutions for swine wastewater treatment. as they efficiently remove suspended solids, biodegradable organic matter and pathogenic microorganisms. Nitrogen removal depends on the system's design, process configuration and loading rates (Kadlec et al., 2000). Detoxification is another important issue, as CWs can remove heavy metals, persistent organic substances and emergent pollutants (Reyes-Contreras et al., 2011). Swine slurry is high-strength wastewater, so treatment with $\mathrm{CW}$ has usually required the implementation of pre-treatment operations or even influent dilution (Hunt and Poach, 2001). Treatment efficiency varies for different pollutants and changes considerably in space and time, depending mostly on the type of CW used, its design, age of the system, feeding mode (how wastewater is applied), hydraulic load (HL) and hydraulic retention time (HRT). Under the effect of different temperatures, treatment efficiency tends to change during the year (Politeo, 2013). Politeo (2013) has compiled experiences using CWs for pig farm effluents and created a "piggery wastewater treatment wetlands database" (PWDB).

Existing treatment wetlands for swine slurry have a wide variety of configurations, designs, flow rates, and inlet qualities (Luo et al., 2018; Vidal et al., 2018; Mendieta-Pino, 2019). The majority of these case studies use free water flow systems to avoid clogging, but require a significant land area. Subsurface systems for piggery wastewater are primarily used in China and Europe. 
Within SSFCWs type, the Horizonal Flow Constructed Wetlands (HFCWs) are the most used system (Borin, et al., 2013; Vidal et al., 2018). However theses CWs requires very effective pretreatments since they are susceptible to clogging. Most of the these experiments treat "pre-treated" swine slurry, as can be noticed with the inlet organic matter and nitrogen concentrations ( $<100 \mathrm{mg} / \mathrm{L}$ COD and $<100 \mathrm{mg} / \mathrm{L}$ TKN). Hence, these CWs are supplementary treatments of ponds, anaerobic digesters or activated sludge reactors meant to reduce nitrogen by nitrification and denitrification. In order to reduce the inlet loads, some studies treat swine slurry by recirculation or adding runoff or tap water for diluting the ammonium content than can be toxic for plants (Harrington and Scholtz, 2010). Vertical Flow Constructed Wetlands (VFCWS) or hybrid systems (combination of different types of CWs) are being applied more recently to treat pig slurry (Liu et al., 2015). Kato et al. (2010), and Klomjek (2016) studied the performance of a hybrid system treating very concentrated pig slurry. In the Kato's study the high TN concentration in swine effluents caused problems with respect to oxygen supply in the plant's vertical filters. In Klomjek's study (2016) experiment Napier grass showed their suitability to be used in the VFCW for swine wastewater treatment, but. However, the TKN of influent swine of the VFCW was $70 \mathrm{mg} / \mathrm{L}$ on average in Klomjek's study compared to more than $2000 \mathrm{mg} / \mathrm{L}$ in this study. In general, a good solid removal prior wetland treatment is necessary to assure a long term functionality, however, if a CW is designed following the concept of French Reed Beds or dewatering reed beds, higher SS charges could be applied to the CW. French Reed Beds are a particular CW solution which receives raw wastewater, hence can receive high SS, organic matter and nutrients loads.

In this context, an innovative CW hybrid system (a new design of VFCW based on French Reed Beds and dewatering reed beds followed by a HFCW, both planted with Phragmites australis) was designed and constructed at a pig farm in Viver i Serrateix (Barcelona province, Catalonia). The main purpose of the study was to evaluate the viability of the hybrid CW to directly treat swine slurry for further land application or discharge in water bodies with reduced nitrogen impact. This paper presents the study of the effectiveness of the hybrid pilot, and evaluates the influence of design (type of flow, presence of Phragmites) and operational parameters (dosing and feeding modes) on treatment efficiency and hydraulic behavior. The nitrogen dynamics to study the capacity of nitrification/denitrification of the CWs is also presented.

\section{MATERIAL AND METHODS}

\section{Study Site}

The study was carried out at a private pig farm, Can Corominas, in Viver i Serrateix, in the Berguedà region of Catalonia (Spain), at an altitude of $606.4 \mathrm{~m}$ above sea level, with a Mediterranean climate and an average annual temperature of $12.9^{\circ} \mathrm{C}$ and average daily temperatures ranging from 1 to $29^{\circ} \mathrm{C}$. Annual rainfall is

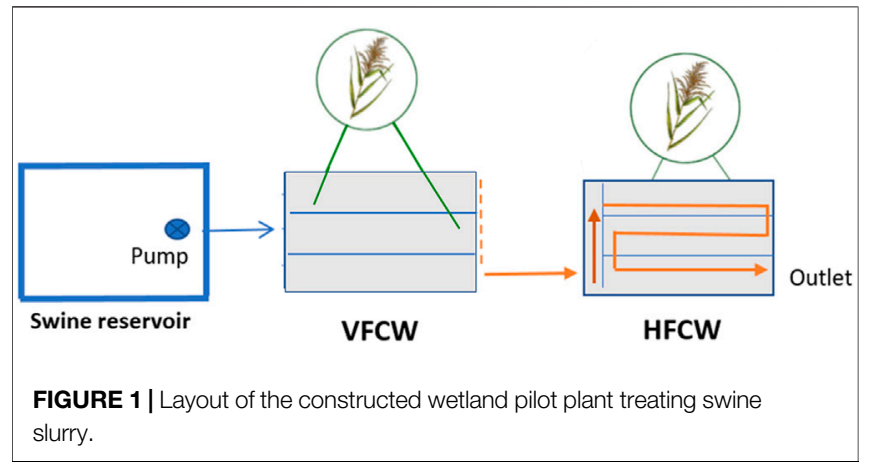

$660 \mathrm{~mm}$. The farm has an area of $1 \mathrm{ha}$, and it accommodates approximately 580 sows and 2000 piglets up to $18 \mathrm{~kg}$ in closed bays. The manure is stored in pits down the ground, and once they fill up, it is emptied into two storage ponds with depths between 3 and $5 \mathrm{~m}$. Filling usually happens every 15 days, and the ponds are emptied twice a year by towed cisterns transporting slurry as organic fertilizer to adjacent field crops. The pilot plant for this project was designed, built and operated based on modular systems (Plantdepur) designed by Spanish company MOIX (MOIX, Obres i Serveis, SL) together with the University of Barcelona. This modular system allows for transport and easy installation without much civil work, as well as easily extending the system's capacity. The pilot plant is a hybrid CW made up of a vertical and a horizontal flow connected in series. The general design diagram of the pilot wastewater treating plant is shown in Figure 1.

The pilot plant receives slurry from an accumulation pond with anaerobic nature. The slurry is pumped into the VFCW, whose waters are directed toward the HFCW. Finally, the treated water from the HFCW is diverted into a big slurry accumulation pond. The main design parameters of the hybrid pilot plant are shown in Table 1.

The vertical system was designed based on the model developed by the IRSTEA (now INRAE) in France (with several beds in parallel and operated intermittently and sequentially), and it can treat raw wastewater without pretreatment as long as rest periods and intermittent feeding are applied to prevent clogging (Molle et al., 2006; Morvannou et al., 2015). The tank is divided into three equal, independent, isolated units with an area of $3.2 \mathrm{~m}^{2}$ each $(4.7 \times 0.7 \times 0.6 \mathrm{~m})$. The filling media is the same for the three units and consists of this vertical section:a filtering layer of $30 \mathrm{~cm}$ of $2-8 \mathrm{~mm}$ gravel, a transition layer of $20 \mathrm{~cm}$ of $20-30 \mathrm{~mm}$ gravel and a drainage layer $10 \mathrm{~cm}$ deep, with $20-60 \mathrm{~mm}$ gravel. One of the units is not planted with Phragmites australis to check the effect of macrophytes. Swine slurry is supplied by means of a pump regulated by a timer. An overflow pipe was installed to control the hydraulic load (HL). The swine slurry is directed to a distributor where water is sent to any of the three distribution pipes that feed each VFCW unit (Figure 2). A tile is placed on the bed down the pipe outlet to prevent local erosion and help distribute water evenly across the surface. Water flows vertically and is collected at the bottom. The water from the VFCW is directed to the horizontal module by gravity 
TABLE 1 | Main design parameters for the hybrid Constructed Wetland.

\begin{tabular}{|c|c|c|}
\hline & \multicolumn{2}{|c|}{ HYBRID SYSTEM } \\
\hline & Vertical flow constructed wetland & Horizontal flow constructed wetland \\
\hline Pre-treatment & Reservoir & VFCW \\
\hline Modular tank & Galvanize steel (3) & Galvanized steel (1) \\
\hline Tank size & $4.6 \times 0.7 \times 0.6 \mathrm{~m}$ & $4.6 \times 2.3 \times 0.6 \mathrm{~m}$ \\
\hline Filling media & $\begin{array}{l}30 \mathrm{~cm} \text { gravel }(2-8 \mathrm{~mm}) \\
20 \mathrm{~cm} \text { gravel }(20-30 \mathrm{~mm}) \\
10 \mathrm{~cm} \text { gravel }(20-60 \mathrm{~mm})\end{array}$ & Crushed brick $(2-8 \mathrm{~cm})$ \\
\hline Vegetation & 2 beds with Phragmites australis 1 bed unplanted & Phragmites australis \\
\hline
\end{tabular}

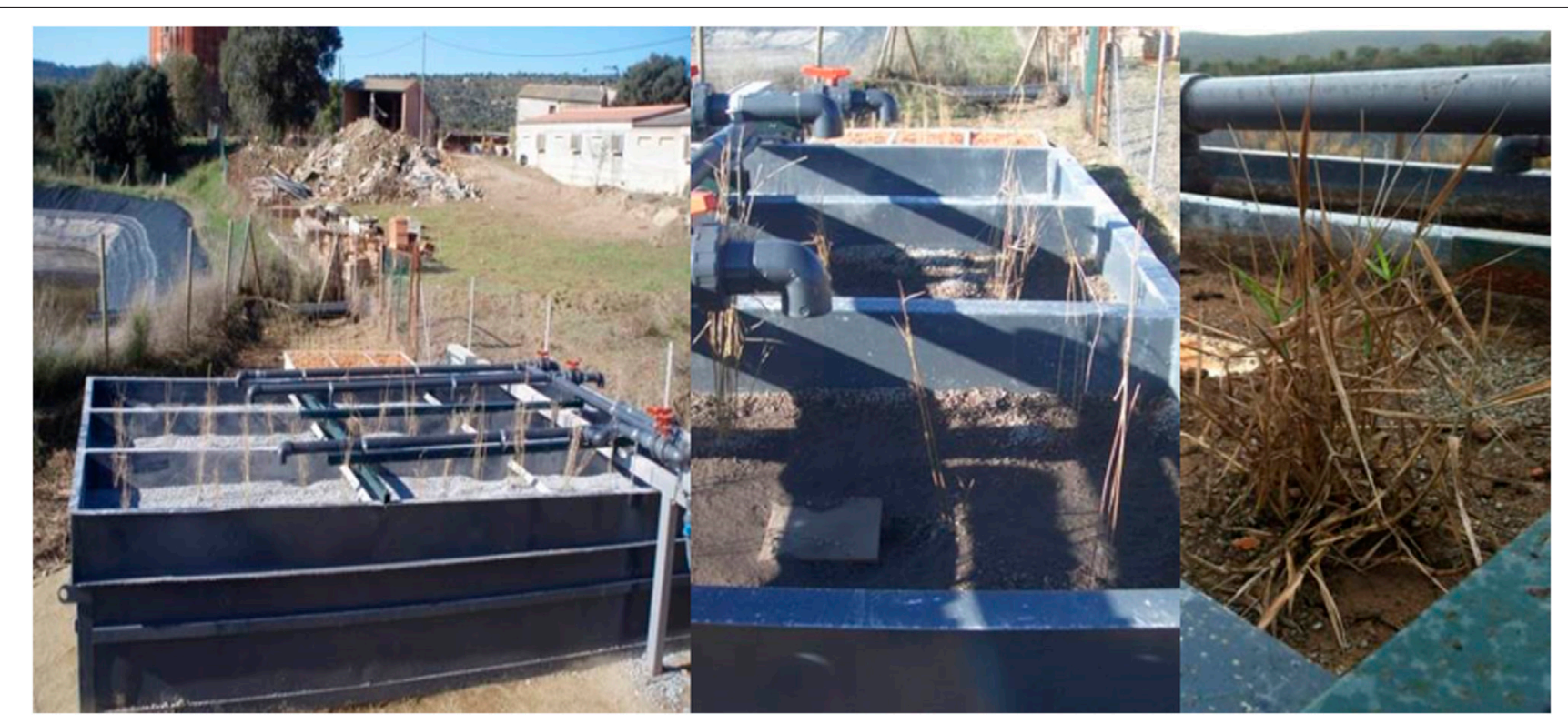

FIGURE 2 | VFCW pilot: general view, distribution pipe and Phragmites australis detail.

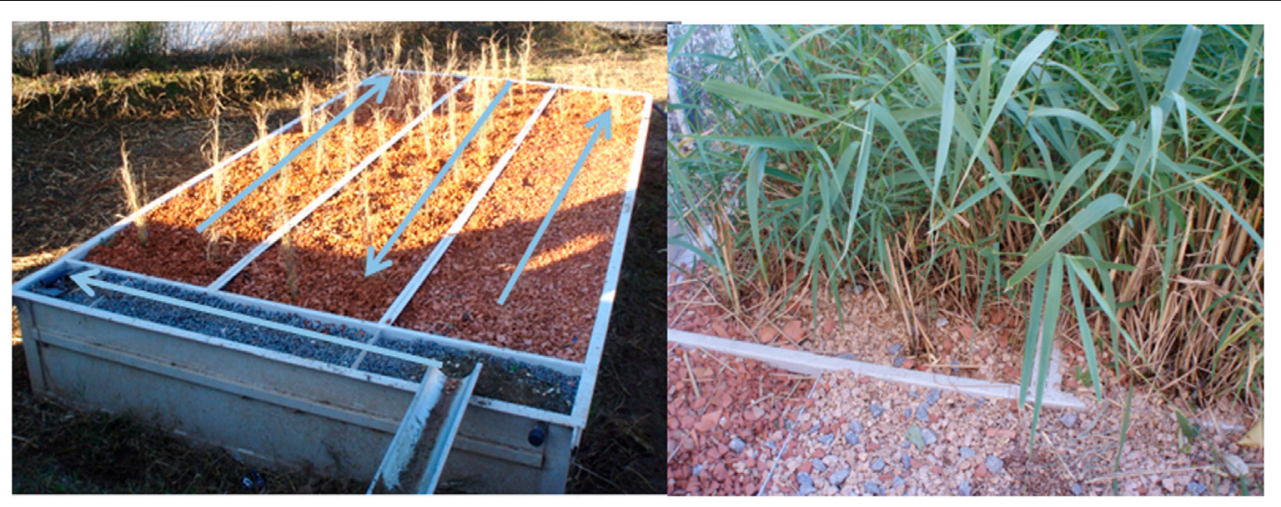

FIGURE 3 | HFCW pilot: general view and Phragmites australis detail.

through a pipe. In the second HFCW module $(4.7 \times 2.3 \times 0.6 \mathrm{~m})$, water, which sequentially enters as it receives the effluent from the vertical filter, flows in a $14.1 \mathrm{~m}$ circuit (Figure 3 ). The tank is filled with crushed brick between 20 and $80 \mathrm{~mm}$ in diameter and planted with Phragmites australis. The outlet consists of a flexible pipe that controls the water column level in the 
TABLE 2 | Operation parameters of the hybrid Constructed Wetland.

\begin{tabular}{|c|c|c|c|}
\hline & & Vertical Flow Constructed Wetland & Horizontal Flow Constructed Wetland \\
\hline \multirow[t]{4}{*}{$\mathrm{HL}$ and dosing } & Mode 1 & $\mathrm{HL} 5.6 \mathrm{~cm} /$ day filter in operation 1 batch/day (1 batch: $5 \mathrm{~cm} /$ day) & HL $5.6 \mathrm{~cm} /$ day (from VFCW outlet) \\
\hline & Mode 2 & $\mathrm{HL} 5.6 \mathrm{~cm} /$ day filter in operation 5 batches/day (1 batch $1.9 \mathrm{~cm} /$ day) & \\
\hline & Feeding & Pump (discontinuous) & $\begin{array}{l}\text { Gravity (continuous or intermittent flow depending on } \\
\text { the VFCW outlet flow) }\end{array}$ \\
\hline & Operation & Each unit is fed for 1 week and rest for 2 weeks & Continuous (no resting periods) \\
\hline
\end{tabular}

wetland bed. Finally, the effluent exits through a pipe to a big swine slurry storage pond.

\section{Operation}

The pilot plant was constructed in 2011 and has been in operation until 2019. A summary of the operation parameters is shown in Table 2. The VFCW pilot received a HL of $5.6 \mathrm{~cm} /$ day $(180 \mathrm{~L} /$ day). For the same $5.6 \mathrm{~cm} /$ day HL, two dosing regimens were applied varying the feeding schedule in order to study the effect of fractionation on filter performance. Thus, two operating periods were established: the first period applying 1batch per day $(180 \mathrm{~L} /$ batch), and the second period applying five batches per day (36 L/ batch). Filters were fed for 7 days and left resting for 2 weeks. The way water entered the HFCW depended on the HRT of the VFCW units.

\section{Water Quality Monitoring}

Physicochemical parameters were evaluated in each pilot plant (VFCWS inlet, VFCWS outlet, HFCW inlet and HFCW outlet). Analysis of weekly, biweekly or monthly grab samples was performed from 2013 until $2016(\mathrm{n}=78)$. EC, $\mathrm{pH}, \mathrm{COD}, \mathrm{dCOD}, \mathrm{TKN}, \mathrm{N}-\mathrm{NH}_{4}{ }^{+}, \mathrm{N}-\mathrm{NO}_{3}{ }^{-}$, and $\mathrm{P}-\mathrm{PO}_{4}{ }^{3-}$ were analyzed according to the Standard Methods (APHA et al.2012). Microbiological parameters were evaluated in each pilot plant component (VFCWS inlet, VFCWS outlet, HFCW inlet and HFCW outlet). The bacteriological indicator (E. coli) was evaluated according to the Standard Methods protocol (APHA et al., 2012).

\section{Sludge Deposit Monitoring}

Samples of sludge accumulated on the surface of the VFCWs were collected every 3 months $(n=16)$ from 2014 to 2016 to monitor the degree of mineralization and composition as fertilizer. Dry Matter (DM), Organic Matter (OM)\%, N\% and $p \%$ were analyzed according to MAPA, 1994.

\section{Hydraulic Monitoring}

In the VFCWs units, Infiltration Rates (IR) per filter were quantified by measuring the level of the surface water with an ultrasound probe during all the operation period (2012-2018). The water level increases during the feeding period and then decreases. During this decreasing period, the IR was calculated in relation to the measurement period by determining the slope rate of change in the height of the water curve of the filter over time. All data were recorded on a data logger minute by minute. Every week, the recorded data were downloaded for evaluation.

\section{Temperature Monitoring Inside the Filters}

Two temperature sensors placed at a depth of $15 \mathrm{~cm}$ were also installed in a planted VFCW unit and in the unplanted VFCW unit. The temperature sensors would contribute to explain the differences caused by the presence of vegetation. These data were recorded on a data logger minute by minute during all the operation period. Every week, the recorded data were downloaded for evaluation.

\section{Biomass Inside the Filters}

Ammonium and nitrite oxidizing bacteria inside the VFCW units were identified by using the Nitri-Vit (Vermicon) test kit. Samples (3 samples per VFCW filter) were collected from the filter at $15 \mathrm{~cm}$ depth after one week of operation and analyzed with this Nitri-Vit test using fluorescent microscopy.

\section{Statistical Analysis}

Statistical analysis of the raw data was done using the statistics computer packages Excel 2010 and SPSS 16.0. for Windows. Excel 2010 was used for descriptive statistics (i.e. averages, SD) and to perform simple regression analysis. SPSS 16.0 was used to analyze variance (two-way ANOVA) to study the effect of variables (presence of Phragmites australis and feeding modes) on the VFCW percentage removals. The level of significance $(p)$ was established at $p \leq 0.05$. The data from these test parameters were tested for normal distribution with box-plot and were log-transformed it they were not normally distributed.

\section{RESULTS AND DISCUSSION}

\section{Influent Characterization}

The average, maximum and minimum concentrations of VFCWs influent pollutants are shown in Table 3. Influent wastewater presented the typical characteristics of swine slurry (Lee et al., 2014; Vidal et al., 2018), with high concentration of SS, organic matter, nitrogen and phosphorous. However, most CW studies, as shown in Table 3, present lower influent pollutant concentrations (most CWs operate with pre-treated wastewater). Only Sánchez-García et al. (2010) and Kato et al. (2010) apply a similar high-strength influent.

The influent presents high variability. The average SS content was $4,000 \mathrm{mg} / \mathrm{L}$ with high variations (from approximately $1,500-10,000 \mathrm{mg} / \mathrm{L}$ ) as a result of each bed (filter in operation) 
TABLE 3 | Hybrid CW performance: average, maximum and minimum influent and effluent concentration and \% removal of pollutants $(\mathrm{n}=78)$.

\begin{tabular}{|c|c|c|c|c|c|c|c|c|c|c|c|c|}
\hline \multirow[t]{2}{*}{ Parameter } & \multicolumn{3}{|c|}{ Influent quality } & \multicolumn{4}{|c|}{$\begin{array}{l}\text { Vertical Flow Constructed Wetland } \\
\text { Effluent quality and \% removal }\end{array}$} & \multicolumn{4}{|c|}{$\begin{array}{l}\text { Horizontal Flow Constructed Wetland } \\
\text { Effluent quality and \% removal }\end{array}$} & \multirow{2}{*}{$\begin{array}{c}\begin{array}{c}\text { TOTAL } \\
\text { REMOVAL }\end{array} \\
\%\end{array}$} \\
\hline & Average & Min & Max & Average* $^{*}$ & Min* & $\operatorname{Max}^{*}$ & $\%$ & Average & Min & Max & $\%$ & \\
\hline EC (mS/cm) & 15.2 & 13.4 & 19.3 & 13.4 & 3.4 & 18.7 & - & 12.4 & 8.1 & 15.1 & - & - \\
\hline $\mathrm{pH}$ & 7.6 & 7.4 & 8.1 & 8 & 7.3 & 8.3 & - & 8.1 & 7.5 & 8.7 & - & - \\
\hline SS (mg/L) & 4,123 & 765 & 19,537 & 956 & 165 & 4,023 & 76.8 & 235 & 16 & 671 & 75.4 & 94.3 \\
\hline $\mathrm{DM}(\mathrm{g} / \mathrm{L})$ & 12.1 & 7.1 & 21.2 & 6.6 & 6.4 & 7.5 & 45.5 & 5.2 & 5.1 & 5.8 & 21.2 & 57.0 \\
\hline BOD5 (mg/L) & 2,124 & 520 & 4,750 & 945 & 324 & 2,465 & 55.5 & 520 & 19 & 1,041 & 45.0 & 75.5 \\
\hline COD (mg/L) & 6,985 & 3,514 & 16,785 & 3,245 & 1865 & 10,245 & 53.5 & 1820 & 444 & 3,985 & 43.9 & 73.9 \\
\hline dCOD (mg/L) & 3,125 & 875 & 12,874 & 2,465 & 345 & 6,214 & 21.1 & 1,130 & 133 & 2,633 & 54.2 & 63.8 \\
\hline TKN (mg/L) & 2,345 & 1,038 & 3,752 & 1,345 & 647 & 2,374 & 42.6 & 715 & 120 & 1,485 & 46.8 & 69.5 \\
\hline $\mathrm{N}-\mathrm{NH} 4+(\mathrm{mg} / \mathrm{L})$ & 1876 & 1,078 & 2,654 & 1,132 & 598 & 1812 & 39.7 & 698 & 172 & 1,058 & 38.3 & 62.8 \\
\hline N-NO3-(mg/L) & 31 & 0 & 102 & 439 & 41 & 564 & $\star \star$ & 154 & 12 & 425 & 64.9 & $\star \star$ \\
\hline P-PO43- (mg/L) & 267 & 62 & 874 & 117 & 15 & 284 & 56.2 & 49 & 6 & 120 & 58.1 & 81.6 \\
\hline
\end{tabular}

*Average for the three VFCWs, ** Nitrification.

receiving an average of $230.8 \mathrm{~g}$ of $\mathrm{SS} / \mathrm{m}^{2}$.day, and $76.9 \mathrm{~g}$ of SS/ $\mathrm{m}^{2}$.day for the whole VFCW pilot, which represents approximately $28 \mathrm{~kg}$ of $\mathrm{SS} / \mathrm{m}^{2}$.year. This value is similar to SDRBs applied with primary or secondary sludge (Troesch, 2009; Arroyo et al., 2018). French VFCWs treating raw wastewater receive much lower loads (about $150 \mathrm{~g}$ of SS/ $\mathrm{m}^{2}$.day with the filter in operation). Most of the CWs experiences treating swine slurry also applies lower SS surface loading rates than this study. The average value of influent DM was $12 \mathrm{~g} / \mathrm{L}$. Similar concentrations of DM are found in the literature for different types of sludge applied to SDRBs: Koottatep et al. (2005) applied sludge from emptying septic tank (with a DM content of $12 \mathrm{~g} / \mathrm{L}$ ) to SDRBs in Thailand, and Burgoon et al. (1997), describes in his study with SDRBs the application of sludge from an aerated pond with a DM content of $14 \mathrm{~g} / \mathrm{L}$. The DM value of $12 \mathrm{~g} / \mathrm{L}$ represents $87 \mathrm{~kg}$ of $\mathrm{DM} / \mathrm{m}^{2}$ per year (filter on operation) and $27 \mathrm{~kg}$ of $\mathrm{DM} / \mathrm{m}^{2}$ per year (entire VFCW). These values are similar of those applied in SDRBs. Nielsen et al. (2005) recommend a maximum of $60 \mathrm{~kg}$ of $\mathrm{DM} / \mathrm{m}^{2}$ per year for the all SDRBs. SDRBs are implemented to treat sludge from activated sludge systems, primary sludge and sludge from emptying septic tanks (Molle, 2014). Organic loads presented a high variability in the study, ranging from 3,600 to $14,000 \mathrm{mg} / \mathrm{L}$ of total COD with a very high average organic load of $391.2 \mathrm{~g}$ of $\mathrm{COD} / \mathrm{m}^{2}$.day (filter in operation) and $130.4 \mathrm{~g}$ of $\mathrm{COD} / \mathrm{m}^{2}$.day (the whole system) depending, again, on the farm operation and storage conditions. About $50 \%$ of the COD was dissolved $\mathrm{COD}$. The $\mathrm{BOD}_{5} / \mathrm{COD}$ ratio presented values of 0.25-0.42 which represents a moderate biodegradability (Tchobanoglous et al., 2003). The influent entering the VFCWs presents intermediate biodegradability. Regarding nitrogen forms, influent is characterized by high $\mathrm{N}^{-\mathrm{NH}_{4}}{ }^{+}$ concentration (most of the nitrogen is ammonium, typical in raw swine slurry). As shown in Table 3, during the monitoring period, TKN influent concentration ranged from 1,100 to $270 \mathrm{mg} / \mathrm{L}$, with a median load of $131.3 \mathrm{~g} \mathrm{TKN} / \mathrm{m}^{2}$.day (filter in operation) which was higher than almost all the values reported in the literature for CWs (Borin et al., 2013; Mendieta et al., 2019). Only Sánchez-García et al. (2010) and Kato et al. (2010) presents similar values. $\mathrm{N}^{-\mathrm{NH}_{4}}{ }^{+}$influent concentration ranged from 1,000 to $2,100 \mathrm{mg} / \mathrm{L}$, which represents a load of $105.1 \mathrm{~g} \mathrm{~N}^{-\mathrm{NH}_{4}}{ }^{+}$/ $\mathrm{m}^{2}$.day, again, higher than almost all the values reported in the literature. The high concentration of ammonium caused problems for plant development, so the filters performed almost like unplanted filters. Sánchez-García et al. (2010) also report problems in macrophyte growing in their studies. It seems that the ammonium content was toxic for the Phragmites, which barely developed. Hunt et al. (2004) indicate that high organic loading rates can increase the risk of ammonium toxicity in some constructed wetland plants. The most commonly used macrophytes for all type of wastewaters and in the studies of CWs treating swine slurry are Phragmites and Typha (Scholz, 2006). More recently, Glyceria has being used because of its high tolerance to ammonium toxicity (Tylova-Munzarova et al., 2005). Also, Klomjek (2016) performed an study using Giant Napier grass (Pennisetum purpureum) and Dwarf Napier grass (Pennisetum purpureum) in a VFCW in Thailand, and both species of Napier grass showed their suitability to be used in the VFCWs for swine wastewater treatment. Wastewater dilution with clean water, or recirculation to improve nutrient removal, is a common practice in constructed wetland operation, particularly if the wastewater can be slightly toxic for plants. Heavily polluted wastewater can also be diluted by less contaminated waters such as roof runoff. Phosphate variability was very high and may be attributable to storage conditions and farm management. The concentration of E. coli was high (Table 4), around 6.3 ULog, slightly higher than in urban wastewater.

\section{Performance of the Hybrid Pilot: Effluent Quality and Removal of Pollutants}

The average, maximum and minimum influent and effluent concentration $(\mathrm{mg} / \mathrm{L})$ and removal efficiency (\%) in the hybrid CW for the physico-chemical parameters are presented in Table 3. The VFCWs presented good removal percentages, in general, for all the parameters. The SS concentration in the filters 'outlet was lower, confirming the filtering capacity of VFCW, with removal rates of about $75 \%$. HFCW after the vertical filters 
TABLE 4 | E. coli concentration (Log CFU/100 ml) and removal (Ulog) (n=78).

\begin{tabular}{|c|c|c|c|c|c|c|}
\hline & \multicolumn{3}{|c|}{ VFCW* } & \multicolumn{3}{|c|}{ HFCW } \\
\hline & Inlet (LogCFU/100 ml) & Outlet (LogCFU/100 ml) & Removal Ulog & Outlet (LogCFU/100 ml) & Removal Ulog & TOTAL REMOVAL Ulog \\
\hline E. coli & 6.3 & 5.3 & 1 & 3.6 & 1.7 & 2.7 \\
\hline
\end{tabular}

${ }^{a}$ Average for the three VFCWs.

upgraded the quality of SS, thus reaching a final quality of approximately $230 \mathrm{mg} / \mathrm{L}$. The long HRT of the HFCW allowed sedimentation of almost all SS. Organic matter removal $\left(\mathrm{BOD}_{5}\right.$ and COD) was about $50 \%$ in the VFCW, despite the high influent load. Oxidation of organic matter was very high, despite the big organic loads. The HFCW received average organic matter loads of $15.7 \mathrm{~g} \mathrm{BOD}_{5} / \mathrm{m}^{2}$.day and $54 \mathrm{~g} \mathrm{COD} / \mathrm{m}^{2}$.day. The HFCW after the VFCW also had good removal rates (about $50 \%$ on average), thus reaching a final removal rate for the whole system of $74 \%$ for $\mathrm{dCOD}$ and $64 \%$ for COD. The vertical flow filters also nitrified the piggery wastewater, with TKN and $\mathrm{N}-\mathrm{NH}_{4}{ }^{+}$removal of about $40 \%$ and producing high concentration of nitrates, thus confirming the filters oxidation capacity thanks to batch feeding and resting periods. The HFCW received average nitrogen loads of $22.3 \mathrm{~g} /$ $\mathrm{m}^{2}$.day for TKN and $18.8 \mathrm{~g} / \mathrm{m}^{2}$.day for $\mathrm{N}^{-\mathrm{NH}_{4}}{ }^{+}$. HFCW reduced total nitrogen, as the system partially denitrified the HFCW inlet nitrates (VFCW inlet). The average removal rates for the HFCW were $46.8 \%$ for TKN, 38.3\% for $\mathrm{N}-\mathrm{NH}_{4}{ }^{+}$and $64.9 \%$ for $\mathrm{N}-\mathrm{NO}_{3}{ }^{-}$. The final effluent contains an average $598 \mathrm{mg} / \mathrm{L}$ of $\mathrm{N}^{-\mathrm{NH}_{4}}{ }^{+}$, $715 \mathrm{mg} / \mathrm{L}$ of $\mathrm{TKN}$ and $154 \mathrm{mg} / \mathrm{L}$ of $\mathrm{N}^{-N_{3}}{ }^{-}$, despite the high inlet concentration of swine slurry. Next section (nitrogen compounds profile) details the behavior of nitrogen compounds in the hybrid pilot. Phosphorus was reduced averaging $86 \%$ removal. It is noteworthy that after 10 months of operation, removal decreased to $30 \%$ due to saturation of phosphorus adsorption, so it is expected that such reduction will decrease more in the next few years. A longer monitoring period is needed to study the efficiency of phosphorus removal in these systems. Phosphorus removal is closely related to the physical, chemical and hydrological properties of the filtering material, as it is physically or chemically adsorbed mainly by ligand exchange. However, a decrease in the concentration of soluble inorganic phosphorus is linked to biological activity, either by macrophyte assimilation or removal through microbiological processes (Molle, 2003). In both processes, adsorption and biological phosphorus uptake, accumulation capacity is finite. As the wetland reaches its stable state, when it is no longer capable of adsorbing if plants are not removed any more phosphorus, elimination decreases dramatically (Vymazal, 2007; Torrens, 2015). Removal of phosphorus by the plants (plant uptake) in the VFCWs can be considered negligible as the plants developed poorly. Part of the phosphorus was also retained and accumulated in the sludge on the top of the filters, as will be discussed following.

Regarding bacterial indicators (Table 4), the average E. coli VFWC inlet and outlet concentration $(n=78)$ were 6.3 Log CFU/ $100 \mathrm{ml}$ and $5.3 \log \mathrm{CFU} / 100 \mathrm{ml}$ respectively with one Ulog removal. Similar reductions were found in the other studies with VFCWs of $65-100 \mathrm{~cm}$ depth (Torrens, 2015). However, filters of $30 \mathrm{~cm}$ with fine sand (Torrens et al., 2009b) presented

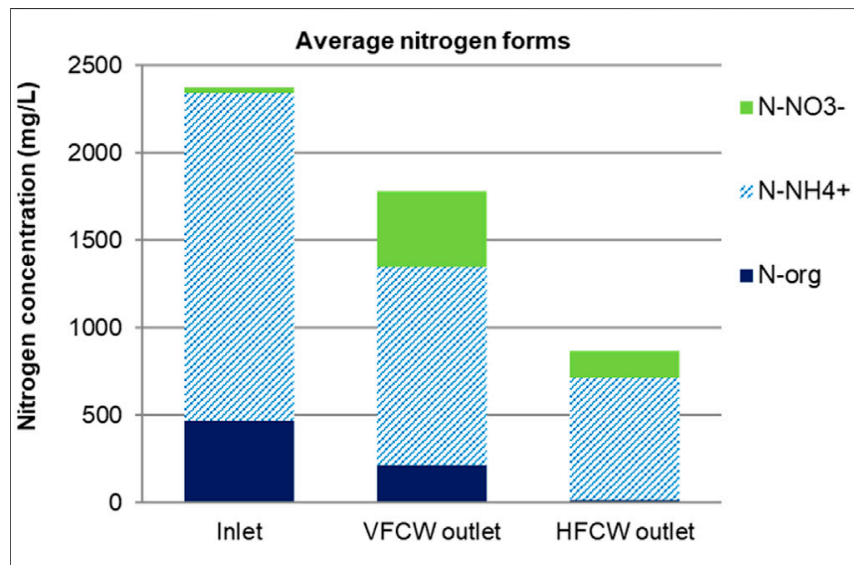

FIGURE 4 | Average nitrogen forms in the hybrid system $(n=78)$.

lower removal rates than these VFCWs. Those shallow filters always showed removal rates $<1$ Ulog. The higher removals observed in the case of the VFCWs could be explained because of sludge accumulation on the top of the filters. This sludge layer diminishes infiltration rate thus increasing retention time. Hydraulic retention time is a key factor in removal of bacterial indicators. The higher the retention time, the higher the removal (Torrens et al., 2010; Torrens, 2015). Moreover, this sludge layer can increase filtration capacity, thus enhancing E. coli removal by filtration The average E. coli HFWC outlet concentration $(\mathrm{n}=78)$ was $3.6 \mathrm{Log} \mathrm{CFU} / 100 \mathrm{ml}$ with $1.7 \mathrm{Ulog}$ removal, being the total removal was 2.7 Ulog. The HFCW removed 1.7 Ulog E. coli, which is within the usual range of HFCW removal (between one to two Ulog) (Huertas, 2009; Sasa, 2014). The combination of HFCW and VFCW reached 2.7 Ulog in total, providing an outlet quality of about $3 \times 10^{3} \mathrm{CFU} / 100 \mathrm{ml}$ of E. coli.

Effluent quality of the hybrid system was not suitable for discharge in water bodies (EU directive 91/271/CEE), but important elimination of nitrogenous components, as well as of organic matter, phosphorus, and even some disinfection, is achieved. To fulfill the quality levels required to discharge in sensitive water areas $\left(\mathrm{BOD}_{5} 25 \mathrm{mg} / \mathrm{L}, \mathrm{COD} 125 \mathrm{mg} / \mathrm{L}, \mathrm{TN} 15 \mathrm{mg} /\right.$ $\mathrm{L}, \mathrm{TP} 2 \mathrm{mg} / \mathrm{L}$ ) a modification of the design and operation strategy is required.

\section{Nitrogen Compounds Profiles}

In terms of nitrogen, the influent is basically composed of ammonium and a small part of organic nitrogen. Around $80 \%$ of the nitrogen present in the slurry is in the form of ammonium. 


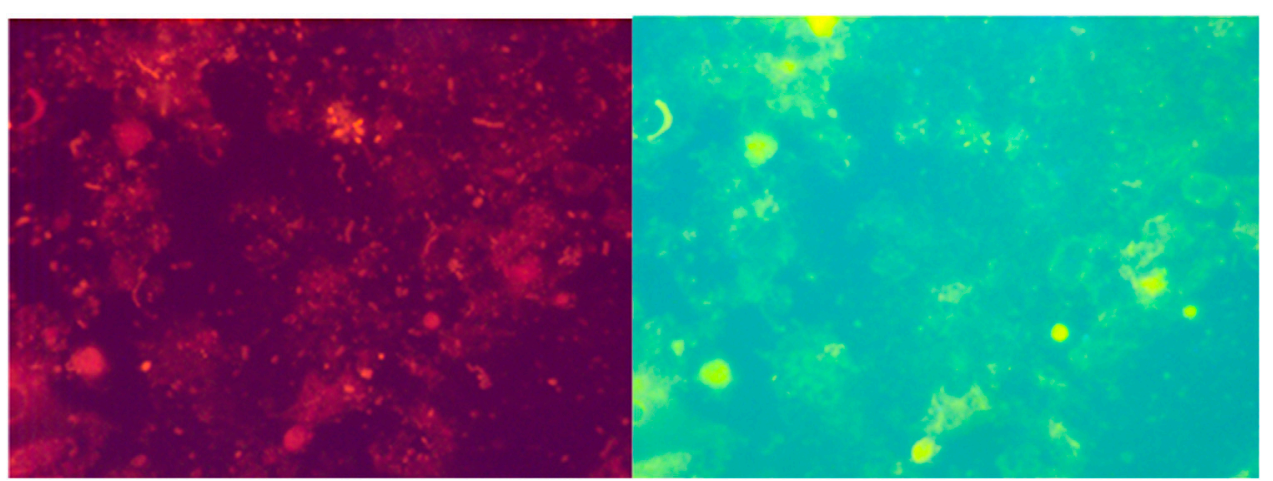

FIGURE 5 | Fluorescence image (ammonium oxidizers and nitrite oxidizers).

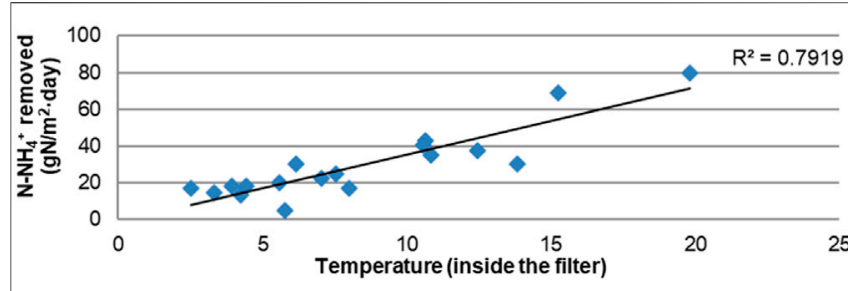

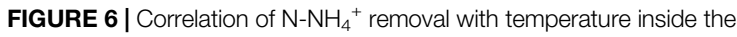
filter and effect of temperature on TKN removal in the VFCW (Filter 1, $\mathrm{HL}=$ $5.6 \mathrm{~cm} /$ day, one batch/day).

Figure 4 shows the average hybrid CW influent and effluent nitrogen forms.

In the VFCWs effluent, the content of ammonium and organic nitrogen has decreased considerably. Part of the influent nitrogen is retained in the sludge accumulated on the filter surface. Plant uptake could also be considered negligible as the plants did not properly develop. Moreover, the results shown in next section do not show any differences in nitrogen removal rates. The main nitrogen removal in these VFCWs is achieved by biological processes that convert organic and ammonium nitrogen into nitrate in an aerobic environment (nitrification). To be really efficient in nitrification, the filters should be in fully aerobic condition, which means that the sand must be kept quite continuously unsaturated and drained. To distribute the effluent evenly over the whole filter surface, a batch feeding system must be installed together with a distribution network. This ensures that the effluent to be treated will reach all filter points as fast as possible to avoid both over and under loaded areas. There is proof that batch feeding enhances aeration by convection, which acts as a plug flow to push the gas below the water level and aspirate the air from the atmosphere over it, once the filter surface is free of water. The batch operation provides aeration of the gravel substrate and exposes the internal biofilms to atmospheric oxygen. During the cycle's drain phase, atmospheric oxygen causes enhanced ammonium and organic matter oxidation (Kadlec and Wallace, 2008). The Nitri-vit kits analysis showed the

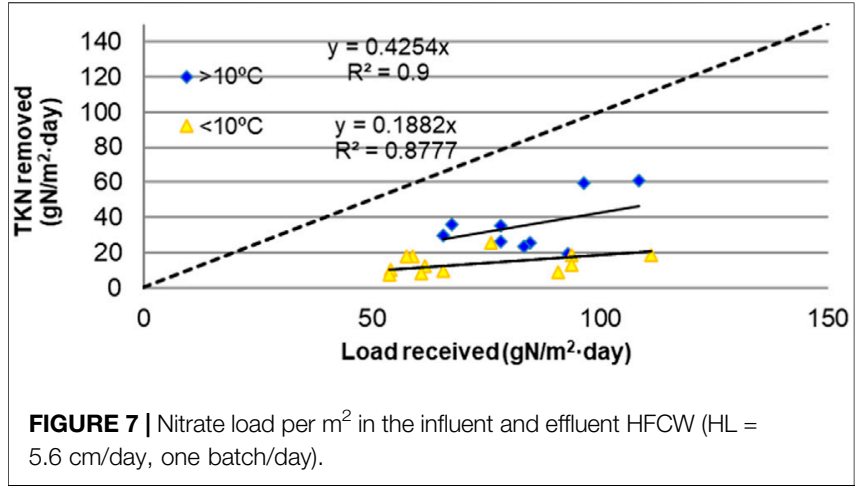

presence of ammonium oxidizer and nitrite oxidizers microrganisms (Figure 5) inside the VFCW filters, demonstrating the filters' oxidation capacity despite the high organic loads applied.

Nitrifying bacteria are sensitive to environmental changes. Among the inhibiting factors are high concentrations of ammonium, low temperatures, a $\mathrm{pH}$ out of the range between 6.5 and 8.6 and an amount of dissolved oxygen below $1 \mathrm{mg} / \mathrm{L}$ (Ogden and Campbell, 1999). It is well known that temperature plays a critical role in metabolism rate of the bacterial species and is a limiting factor in the transformation processes of nitrogen compounds. Nitrification was affected by temperature, as shown in Figure 4. The correlation of nitrification and temperature results in higher percentages of elimination with increasing temperature. Figure 6 shows TKN removal ( $\mathrm{g}$ TKN $/ \mathrm{m}^{2}$.day removed) of the VFCWs (Filter 1) filter according to two temperature ranges $\left(<10^{\circ} \mathrm{C}\right.$ and $\left.>10^{\circ} \mathrm{C}\right)$. The slope for the $>10^{\circ} \mathrm{C}$ range is higher than for the $<10^{\circ} \mathrm{C}$, confirming that TKN removal is much higher at temperatures inside the filters $>10^{\circ} \mathrm{C}$. Numerous studies have shown that average TKN removal in winter are lower than in summer, most likely because of the lower winter temperature, which was well under optimal temperature for nitrifying activity (Pascual et al., 2018). In the area of the study, winter temperatures are very low, reaching easily $0^{\circ} \mathrm{C}$ in winter time. Therefore, these systems can operate much more efficiently in 
warmer areas, where a filter with similar characteristics and operation would remove much more $\mathrm{TKN} / \mathrm{m}^{2}$.day. If such high TKN removal is not required, the total filter area could be smaller. HFCWs remove the total nitrogen by nitrifying and denitrifying reactions. (Platzer, 1999; Cooper, 2005). Almost all organic nitrogen entering in the HFCW is removed (92\%) and a $38 \%$ of the entering ammonium. More than $50 \%$ of nitrates are denitrified in the HFCW (Figure 7).

Denitrification is a sequential process in which nitrates are gradually transformed into nitric oxide, nitrous oxide, and finally, molecular nitrogen that is liberated into the atmosphere. Heterotrophic microorganisms responsible for this process are mainly aerobic facultative, able to adapt to the environmental conditions in which they find themselves. Heterotrophic microorganisms need a source of organic carbon to oxidize. A proper ratio of $\mathrm{C} / \mathrm{N}$ and readily biodegradable organic matter are essential for good kinetics of the reaction. These nitrificationdenitrification processes are possible in the HFCW thanks to the presence of enough organic matter (and that carbon source) in the VFCW effluent. The optimum $\mathrm{pH}$ for denitrification is between 7.0 and 8.5 (the average $\mathrm{pH}$ in the inlet HFCW was 8 , with a minimum of 7.3 and maximum of 8.3 ). Therefore, the $\mathrm{pH}$ conditions were favourable for the denitrification process in the HFCW. Average total removal of TKN and $\mathrm{N}_{-} \mathrm{NH}_{4}{ }^{+}$by the hybrid CW was $69.5 \%$ and $62.8 \%$, respectively. Similar yields were found by Borin et al. (2013) in a hybrid system with notable TKN and $\mathrm{N}-\mathrm{NH}_{4}{ }^{+}$reductions of 64 and $63 \%$. This is significant, but in our case study, nitrogen and organic loads $/ \mathrm{m}^{2}$. day were much higher. Total nitrogen reduction $\left(\mathrm{TKN}+\mathrm{N}^{-\mathrm{NO}_{3}}{ }^{-}\right.$) was, on average, $63.4 \%$. Therefore, the results show that nitrogen removal by the hybrid CW has effectively reduced the nitrogen content of the pig slurry, thus reducing existing production surplus in this farm. The percentage of this pollutant reduction reached in the study would allow a higher volume of effluent application to agricultural land and enabled more sustainable management of swine slurry in the farm.

Considering a $63.4 \%$ reduction of total nitrogen, the hybrid CW surface required per pig head was roughly estimated. Assuming an average volume of swine slurry of $2 \mathrm{~m}^{3} /$ year with $3 \mathrm{~kg} / \mathrm{m}^{3}$ of nitrogen, the required hybrid CW surface would be approximately $0.11 \mathrm{~m}^{2}$ per head. As indicated above, the percentage of nitrogen removal is strongly related to temperature, so the value obtained can be reduced with the increase of average temperature. Apart from land application, there is another scenario to consider that is to obtain a quality of effluent that could be able to discharge into bodies of water. For discharge in sensitive areas the quality required is $<15 \mathrm{mg} / \mathrm{L}$ for Total Nitrogen (EU Directive 91/271/CEE). This could be achieved in several ways. With the $\mathrm{C}$ and $\mathrm{N}$ concentration of the HFCW effluent, another module of HFCW could be incorporated in series to reduce the total nitrogen and achieve limits close to those of discharge into bodies of water. Another option is to dilute the influent by recirculation to reduce the ammonium content that can be toxic to the plants, like the Harrignton and Scholz (2010) experience in Ireland. At present, a study to improve the effluent quality with a second HFCW and recirculation trials is being conducted to explore the

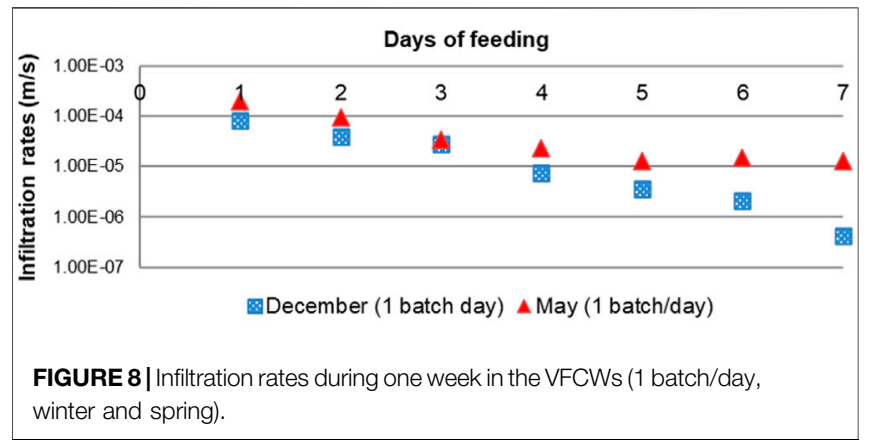

capacity of the system to provide an effluent with suitable quality for disposal on water bodies or reuse. Moreover additional experiments are being carried out to recover $\mathrm{N}$ and $p$ from the CW effluent and the VFCWs sludge, in order to use it as a slowrelease fertiliser (struvite).

\section{Vertical Flow Constructed Wetland Hydraulics}

During all operation period the VFCW pilot received an average $\mathrm{HL}$ of $5.6 \mathrm{~cm} /$ day $(180 \mathrm{~L} /$ day for a batch height of $5.6 \mathrm{~cm})$. For most of the study, the filters received $5.6 \mathrm{~cm} /$ day in one application. For 12 months, the same HL was applied fractioned into five applications of $36 \mathrm{~L}$ each, for a batch height of $1.9 \mathrm{~cm}$. Filters were fed during 7 days and left resting for 2 weeks throughout the study. Continuous monitoring of IRs was a very useful and practical tool to study the filters' hydraulic behavior. The three VFCWs beds presented similar average IRs, ranging from $10^{-4}$ to $10^{-7} \mathrm{~m} / \mathrm{s}$ depending on the day of feeding, operation and temperature. Similar values (though slightly higher) ranging from $10^{-4}$ to $10^{-6} \mathrm{~m} / \mathrm{s}$ were found SDRBs treating primary non-digested sludge (Torrens, 2015). During one week of feeding, the IRs decreases (Figure 8). The same phenomenon was observed in SDRBs treating primary non digested sludge or with the IRs studies of VFCWs treating pond effluent (Torrens, 2015). Fast infiltration at the beginning of each feeding period can be related to differences due to the low humidity conditions inside the filter beds after resting. While filters are fed and become humid, the infiltration rates decrease. In the studied operation conditions, no clogging problems were detected thanks to fixed feeding/resting periods established. With the studied organic loads, the filters' filtration capacity was good for 7 days in winter periods. However, more than 7 days of feeding reduced infiltration capacity to values in the range of $10^{-7} \mathrm{~m} / \mathrm{s}$, as shown in Figure 6. Hence, the feeding/resting cycle of 1 week/2 weeks seems to be well adapted for the studied conditions, with seven being the maximum number of feeding days for VFCWs with air temperature between 1 and $15^{\circ} \mathrm{C}$ for the applied organic loads. In warmer periods (with air temperatures between $15^{\circ} \mathrm{C}$ and $30^{\circ} \mathrm{C}$ ), the infiltration capacity during the seven feeding days remained good (about $10^{-5} \mathrm{~m} / \mathrm{s}$ ) (Figure 8). The high temperatures allow better drying and mineralization of the organic deposits, so that water can infiltrate better. In summer, infiltration capacity was not reduced as much in the seven feeding 


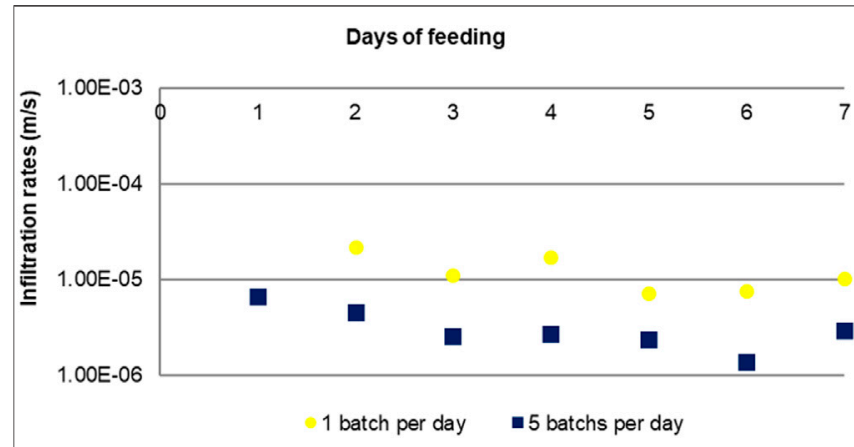

FIGURE 9 | Effects of fractionation of the $\mathrm{HL}$ on infiltration rates.

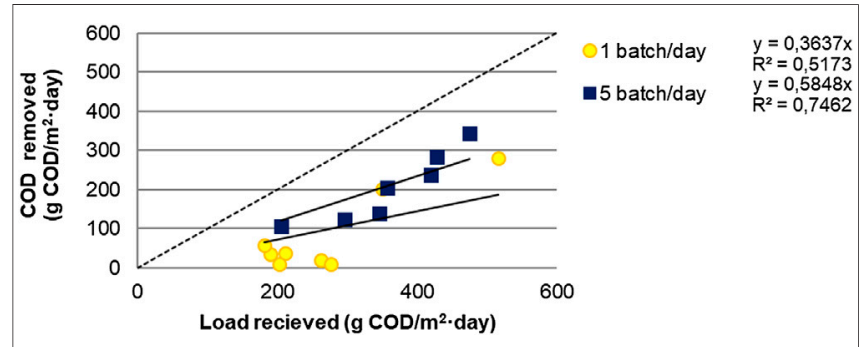

FIGURE 10 | Effects of fractionation of the $H L$ on COD removal efficiency $\left(\mathrm{HL}=5.6 \mathrm{~cm} /\right.$ day) (temperatures between $\left.5-10^{\circ} \mathrm{C}\right)$.

days, so in areas with higher temperatures, feeding periods could be slightly longer with no risk of clogging.

\section{Effect of the Presence of Phragmites australis}

As reported above, Phragmites australis hardly developed at all in the VFCWs, so no statistically differences were found between the planted and unplanted beds (in removal efficiency and hydraulics).

\section{Effects of the Dosing and Feeding Modes}

Figure 9 shows the effects of feeding mode on infiltration rates (1 batch/day or five batches/day). For the same hydraulic load of $5.6 \mathrm{~cm} /$ day, when fractionation is higher (5 batches/day), infiltration rates were lower. When fractionation is higher, the water pressure is lower due the lower batch volume, and moreover, humidity is higher inside the filter because the time elapsed between applications is shorter resulting in lower infiltration rates as the water percolates slowly.

Figure 10 presents the effects of fractionation of the HL on COD removal efficiency ( $\mathrm{HL}=5.6 \mathrm{~cm} /$ day) (temperatures between $\left.5-10^{\circ} \mathrm{C}\right)$. Only COD removal was significantly affected $(p<0.05)$ by the fractionation of the HL, COD removal was better at higher load fractionation. These results match the results of Torrens et al. (2009a) and Torrens et al. (2018): COD removal and nitrogen oxidation appeared to be highly dependent on fractionation. In both
TABLE 5 | Sludge composition (average and SD) throughout the period (samples taken one week after resting) $(n=16)$.

\begin{tabular}{lccccc}
\hline & \%DM & \%VS & \% TKN & ${\text { \% } \mathbf{P}_{\mathbf{2}} \mathbf{O}_{\mathbf{5}}}$ & $\mathbf{\%} \mathbf{N}-\mathbf{N H}_{\mathbf{4}}{ }^{+} / \mathbf{\%} \mathbf{N}-\mathbf{T K N}$ \\
\hline Average & 45.7 & 40.5 & 3.2 & 1.1 & 65 \\
SD & 17.3 & 4.1 & 0.8 & 0.3 & 12.2
\end{tabular}

studies for the same HL, with higher fractionation by decreasing the batch volume, retention time is increased, and there is greater exchange of the less mobile fraction of the pore water. This circumstance affords closer and longer contact between media and pollutants and results in higher purification. Nevertheless, nitrification was not affected by fractionation of the HL in the studied system. Although fractionation can increase retention time in the filters, it can diminish oxygenation, so the removal of nitrogen compounds is not affected.

\section{Characterisation and Effects of Deposits on the Surface of the Vertical Flow Constructed Wetlands}

Part of the dry matter, organic matter and nutrients contained in the applied slurry is retained on the vertical filter surface. The sludge on top of the vertical filters was dried and mineralized in the bed, as happens in the first stage of the French VFCWs treating raw wastewater (Molle, 2014) or SDRBs (Troesch, 2009). This biosolids organic layer appears to be a key component that can favor treatment performance or limit some processes. Indeed, this layer can improve filtration efficiency and, thus, solids removal, water retention time into the system and treatment performance, as long as the media stay in aerobic conditions, and it can reduce permeability of the filter and improve water distribution on the filter's surface. It also allows water to flow in the entire filter volume at lower velocity, favoring ammonium adsorption nitrified between batches or during resting periods, and it is the place of major biological activity, once its thickness becomes significant (Molle, 2014). Nevertheless, hydraulic and organic loads, as well as operating conditions (batch feeding, alternation between feeding and resting periods), have to be closely controlled to encourage deposit mineralization. Otherwise, the deposit layer can generate process limitations, such as waterlogging, oxygen transfer limitation (convection and diffusion) and decreasing biosolids mineralization. All these processes are interdependent. Dry matter content of the accumulated sludge varied from 40 to $60 \%$ depending on the season ( $40 \%$ of DM in winter and $60 \%$ in summer). However, the quality of the sludge was stable, with contents in the range of 40 Vs, $3 \%$ TKN, and $1 \% \mathrm{P}_{2} \mathrm{O}_{5}$ (Table 5).

Percentages of VS, TKN and $\mathrm{P}_{2} \mathrm{O}_{5}$ were constant during the study. DM content varied, mainly depending on the temperature and the loads applied. Percentage of DM contents in other studies is reported as: $30 \% \mathrm{DM}$ and $40-50 \%$ VS, with SDRBs treating sludge from activated sludge systems (Uggeti, 2011). Nutrient values of $2-3 \%$ of TKN and around $1 \%$ of TP are found in the sludge accumulated on the surface of SDRBs treating primary 
sludge from a settling tank (Torrens, 2015). This residue accumulates (and dries and mineralizes) over time, generating a volume that directly affects the system's hydraulics, so it is an important aspect to take into account in the evolution of treatment system design and management for possible final application of this sludge. Dry sludge, which is about $1 \%$ of the total mass of the fresh slurry, could be used for compost or applied to the land as fertilizer with additional analysis. After 2 years of operation, about $25 \mathrm{~cm}$ of sludge were accumulated on the filters.

The values registered by the installed sensors, in addition to providing information about the hydraulic system performance (IRs), have allowed us to estimate the amount of sludge accumulated on the surface of the vertical filter, and the slope of the regression line is identifiable as the ratio of deposit accumulation on the surface (approximately $19.4 \mathrm{~cm} /$ year). This value matches the observed values using a ruler placed on the filters' wall (around $1-2 \mathrm{~cm} /$ month). The deposit layer created in the first stage of the French VFCW accumulates at an average rate of $2.5 \mathrm{~cm} /$ year at nominal load. Koottatep et al. (2005) reports accumulations of $12 \mathrm{~cm} /$ year for SDRBs treating sludge from septic tank emptying. Troesch (2009) displays a compilation of experiences with SDRBs treating different sludge's or wastes and reports accumulations per year ranging from 15 to $60 \mathrm{~cm} /$ year, depending on design, load, operation and type of sludge or influent.

\section{CONCLUSION}

Nature-based technologies, like Constructed Wetlands, have demonstrated their suitability to treat swine slurry from small farms once design and operation has been optimized. The Constructed Wetlands have shown resilience to load and hydraulic fluctuations, to extreme and variable conditions, etc., being simple to operate and maintain with null or minimum energy requirements and with an added aesthetical value. The hybrid system has a dual function (solid-liquid separation and biological treatment), achieving a significant removal of nitrogen $(65 \%)$, as well as of organic matter, phosphorus, suspended solids and partial disinfection. The use of a hybrid system (vertical + horizontal flow) allowed for a reduction of the overall nitrogen load for the swine slurry, thanks to the combined nitrification/ denitrification processes, effectively reducing swine slurry nitrogen content and the volume of effluent applied in agricultural land can significantly increase. Despite the high percentage removal the effluent was not suitable to discharge into water bodies. To fulfill these discharge quality limits an

\section{REFERENCES}

APHA (American Public Health Association), AWWA (American Water Works Association); WPCF (Water Pollution Control Federation) (2012). Standard Methods for the examination of water and wastewater. 22nd Edn. Washington, DC. enhanced design/operation would be required. The VFCW, operated intermittently and with sequential feeding (1 week feeding/2 weeks resting), had good hydraulic performances without clogging problems, despite high pollutant loads. The control of HL, SS surface loading rates, organic loading rates and the feeding and resting periods was of a great importance to avoid clogging and achieve good removals of pollutants. The maximum number of feeding days for VFCWs depended on the organic load, hydraulic load, fractionation of the HL and temperature. Some of the contaminants were retained, dried and mineralized in the surface of the VFCW. This biosolid organic layer improved filtration efficiency, water retention time, treatment performances and could be reused as a subproduct for compost or fertilizer.

\section{DATA AVAILABILITY STATEMENT}

The raw data supporting the conclusions of this article will be made available by the authors, without undue reservation.

\section{AUTHOR CONTRIBUTIONS}

AT, MF and MS conceived of the study. AT and MF carried out the experimental work. AT treated the data, MS and MF supervised the findings of this work. AT wrote the manuscript wrote with support from MF and MS.

\section{FUNDING}

This work was supported by MEDIWAT (1G-MED09-262) project of the EU MED Program and the Spanish Ministry of Science and Innovation (CTM 2010-19197).

\section{ACKNOWLEDGMENTS}

The content of this manuscript has been published in part as part of the thesis of AT, [Torrens, A. (2015). Subsurface flow constructed wetlands for the treatment of wastewater from different sources. design and operation. PhD thesis, Universitat de Barcelona, Spain]. The authors would like to thank the farm Can Corominas, the company MOIX (MOIX, Obres i Serveis, SL), Carlos Bayona, Jihad Sasa and the Department of the Catalan Government through the Consolidated Research Group (2017 SGR 1327).

Armengol, J., and Salgot, M. (2013). "Eutrophication in lakes and dams," in Stagnant Water Bodies Pollution. Editor M. Salgot (Charlottesville, VA: Dikinson Editorial), 12-23.

Arroyo, P., Sáenz de Miera, L. E., Falagán, J., and Ansola, G. (2018). Bacterial community composition and diversity uncovered in experimental sludge treatment reed bed systems with different swine slurry hydraulic loadings. Ecol. Eng. 123, 175-184. doi:10.1016/j.ecoleng.2018.09.009 
Borin, M., Politeo, M., and de Stefani, G. (2013). Performance of a hybrid constructed wetland treating piggery wastewater. Ecol. Eng. 51, 229-236. doi:10.1016/j.ecoleng.2012.12.064

Burgoon, P. S., Kirkbride, K. F., Henderson, M., and Landon, E. (1997). Reed beds for biosolids drying in the arid northwestern United States. Water Sci. Technol. 35 (5), 287-292. doi:10.2166/wst.1997.0219

Cooper, P. F. (2005). The performance of vertical flow constructed wetland systems with special reference to the significance of oxygen transfer and hydraulic loading rates. Water Sci. Technol. 51 (9), 81-90. doi:10.2166/wst. 2005.0293

Harrington, C., and Scholz, M. (2010). Assessment of pre-digested piggery wastewater treatment operations with surface flow integrated constructed wetland systems. Bioresour. Technol. 101, 6950-6960. doi:10.1016/j. biortech.2010.03.147

Henkens, P. L. C. M., and Van Keulen, H. (2001). Mineral policy in the Netherlands and nitrate policy within the European community. NJAS-Wageningen J. Life Sci. 49, 117-134. doi:10.1016/s1573-5214(01)80002-6

Huertas, E. (2009). Regeneració i reutilització d’aigües residuals. Tecnologia, controlirisc. PhD thesis. Barcelona (Spain): Universitat de Barcelona.

Hunt, P. G., Matheny, T. A., and Stone, K. C. (2004). Denitrification in a coastal plain riparian zone contiguous to a heavily loaded swine wastewater spray field. J. Environ. Qual. 33, 2367-2374. doi:10.2134/jeq2004.2367

Hunt, P. G., and Poach, M. E. (2001). State of the art for animal wastewater treatment in constructed wetlands. Water Sci. Technol. 44 (11-12), 19-25. doi:10.2166/wst.2001.0805

Kadlec, R. H., Knight, R. L., Vymazal, J., Brix, H., Cooper, P., and Haberl, R. (2000). "Constructed wetlands for pollution control. Processes, performance, design and operation," in IWA Specialist Group on the use of Macrophytes in water Pollution Control, IWA scientific and technical report No. 8 (London, UK: IWA Publishing).

Kadlec, R. H., and Wallace, S. (2008). Treatment Wetlands. 2nd Edn. Boca Raton, FL: CRC Press.

Kato, K., Inoue, T., Ietsugu, H., Koba, T., Sasaki, H., Miyaji, N., et al. (2010). "Design and performance of hybrid reed bed systems for treating high content wastewater in the cold climate," in Proceedings of 12th International Conference on Wetland Systems for Water Pollution Control, San Servolo Island, Venice, 1, 511-517.

Klomjek, P. (2016). Swine wastewater treatment using vertical subsurface flow constructed wetland planted with Napier grass. Sustain. Environ. Res. 26, 217-223. doi:10.1016/j.serj.2016.03.001

Koottatep, T., Surinkul, N., Polprasert, C., Kamal, A. S., Koné, D., Montangero, A., et al. (2005). Treatment of septage in constructed wetlands in tropical climate: lessons learnt from seven years of operation. Water Sci. Technol. 51 (9), 119-126. doi:10.2166/wst.2005.0301

Lee, S., Maniquiz-Redillas, M. C., Choi, J., and Kim, L. (2014). Nitrogen mass balance in a constructed wetland treating piggery wastewater effluent. J. Environ. Sci. 26 (6), 1260-1266. doi:10.1016/S1001-0742(13)60597-5

Liu, R., Zhao, Y., Doherty, L., Hu, Y., and Hao, X. (2015). A review of incorporation of constructed wetland with other treatment processes. Chem. Eng. J. 279, 220-230. doi:10.1016/j.cej.2015.05.023

Luo, P., Liu, F., Zhang, S., Li, H., Yao, R., Jiang, Q., et al. (2018). Nitrogen removal and recovery from lagoon-pretreated swine wastewater by constructed wetlands under sustainable plant harvesting management. Bioresour. Technol. 258, 247-254. doi:10.1016/j.biortech.2018.03.017

MAPA (Ministerio de Agricultura, Pesca y Alimentación) (1994). Métodos oficiales de análisis. Madrid, Spain: Ministerio de Agricultura, Pesca y Alimentación, Vol. III.

Martinez, J., Dabert, P., Barrington, S., and Burton, C. (2009). Livestock waste treatment systems for environmental quality, food safety, and sustainability. Bioresour. Technol. 100, 5527-5536. doi:10.1016/j. biortech.2009.02.038

Mendieta-Pino, C., Ramos-Martin, A., Perez-Baez, S. O., and Brito-Espino, S. (2019). Management of slurry in Gran Canaria Island with full-scale natural treatment systems for wastewater (NTSW). One year experience in livestock farms. J. Environ. Manag. 232, 666-678. doi:10. 1016/j.jenvman.2018.11.073
Molle, P., Liénard, A., Grasmick, A., and Iwema, A. (2006). Effect of reeds and feeding operations on hydraulic behaviour of vertical flow constructed wetlands under hydraulic overloads. Water Res. 40 (3), 606-612. doi:10. $1016 /$ j.watres.2005.11.026

Molle, P. (2003). Filtres plantes de roseaux: limites hydrauliques et retention du phosphore. PhD thesis. Montpellier (France): Université Montpellier II Sciences et Techniques du Languedoc.

Molle, P. (2014). French vertical flow constructed wetlands: a need of a better understanding of the role of the deposit layer. Water Sci. Technol. 69 (1), 106-112. doi:10.2166/wst.2013.561

Morvannou, A., Forquet, N., Michel, S., Troesch, S., and Molle, P. (2015). Treatment performances of French constructed wetlands: results from a database collected over the last 30 years. Water Sci. Technol. 71 (9), 1333-1339. doi:10.2166/wst.2015.089

Ogden, M., and Campbell, C. (1999). Constructed Wetlands in the Sustainable Landscape. New York, NY: John Wiley \& Sons.

Pascual, A., de la Varga, D., Soto, M., VanOirschot, D., Kilian, R. M., Álvarez, J. A., et al. (2018). "Aerated constructed wetlands for treatment of municipal and food industry wastewater," in Constructed wetlands for Industrial wastewater Treatment. Editor A. I. Stefanakis (John Wiley \& Sons), 65-95.

Platzer, C. (1999). Design recommendations for subsurface flow constructed wetlands for nitrification and denitrification. Water Sci. Technol. 40 (3), 257-263. doi:10.1016/S0273-1223(99)00420-5

Politeo, M. (2013). Performance of hybrid constructed wetland for piggery wastewater treatment. PhD thesis. Italy: Università degli Studi di Padova.

Reyes-Contreras, C., Matamoros, V., Ruiz, I., Soto, M., and Bayona, J. M. (2011). Evaluation of PPCPs removal in a combined anaerobic digester-constructed wetland pilot plant treating urban wastewater. Chemosphere 84 (9), 1200-1207. doi:10.1016/j.chemosphere.2011.06.003

Sánchez-García, P., Caballero, A., Faz, A., and Lobera, J. B. (2010). “A Pig slurry purification option: constructed wetland," in Proceedings of 14th Ramiran International conference on treatment and use of organic residues in agriculture, Lisboa, Portugal, September 14-17, 2010.

Sasa, J. (2014). Influencia de los periodos de llenado y vaciado en la eliminación de nutrients y desinfección en zonas humedas construidas de flujo subsuperficial horizontal, PhD Thesis. Barcelona (Spain): Universitat de Barcelona.

Scholz, M. (2006). Wetland ystems to Control Urban Runoff Elsevier. Amsterdam, Netherlands: Elsevier.

Statistical Institute of Catalonia (2020). Idescat. Statistical Institute of Catalonia. Available at: https://www.idescat.cat/pub/?id=aec\&n=452\&lang $=$ en (Accessed March 10, 2020).

Tchobanoglous, F., Burton, L., and Stensel, H. D. (2003). Wastewater Engineering: Treatment and Reuse. 4th Edn. New York, NY: Metcalf \& Eddy Inc., McGrawHill.

Torrens, A., Folch, M., Salgot, M., and Aulinas, M. (2018). "Recycling of carwash effluents treated with subsurface flow constructed wetlands," in Constructed wetlands for Industrial wastewater Treatment. Editor A. I. Stefanakis (John Wiley \& Sons), 469-493.

Torrens, A., Molle, P., Boutin, C., and Salgot, M. (2009a). Impact of design and operation variables on the performance of vertical-flow constructed wetlands and intermittent sand filters treating pond effluent. Water Res. 43, 1851-1858. doi:10.1016/j.watres.2009.01.023

Torrens, A., Folch, M., Sasa, J., Lucero, M., Huertas, E., Molle, P., et al. (2010). "Removal of bacterial and viral indicators in horizontal and vertical subsurface flow constructed wetlands," in 12th IWA International Conference on Wetland Systems for Water Pollution Control, October 2010, San Servolo, Venice.

Torrens, A., Molle, P., Boutin, C., and Salgot, M. (2009b). Removal of bacterial and viral indicator in vertical flow constructed wetlands and intermittent sand filters. Desalination 246, 169-178. doi:10.1016/j.desal. 2008.03.050

Torrens, A. (2015). Subsurface flow constructed wetlands for the treatment of wastewater from different sources. design and operation. $\mathrm{PhD}$ thesis. Barcelona (Spain): Universitat de Barcelona. 
Troesch, S. (2009). Traitement et valorisation des boues et des matières de vidange par lits de séchage plantés de Roseaux. $\mathrm{PhD}$ thesis. Cemagref, France.

Tylova-Munzarova, E., Lorenzen, B., Brix, H., and Votrubova, O. (2005). The effects of $\mathrm{NH}^{4+}$ and $\mathrm{NO}^{3-}$ on growth, resource allocation and nitrogen uptake kinetics of Phragmites australis and Glyceria maxima. Aquat. Bot. 81, 326-342. doi:10.1016/j.aquabot.2005.01.006

Uggeti, E. (2011). Sewage sludge treatment in constructed wetlands. Technical, economic and environmental aspects applied to small communities of the Mediterranean region. PhD thesis. Barcelona (Spain): Universitat Politècnica de Catalunya.

Vidal, G., Plaza, C., and Sáez, O. (2018). “The performance of constructed wetlands for treating swine wastewater under different operating conditions," in Constructed wetlands for Industrial wastewater Treatment. Editor A. I. Stefanakis (John Wiley \& Sons), 67-95.
Vymazal, J. (2007). Removal of nutrients in various types of constructed wetlands. Sci. Total Environ. 380, 48-65. doi:10.1016/j.scitotenv.2006. 09.014

Conflict of Interest: The authors declare that the research was conducted in the absence of any commercial or financial relationships that could be construed as a potential conflict of interest.

Copyright (c) 2021 Torrens, Folch and Salgot. This is an open-access article distributed under the terms of the Creative Commons Attribution License (CC BY). The use, distribution or reproduction in other forums is permitted, provided the original author(s) and the copyright owner(s) are credited and that the original publication in this journal is cited, in accordance with accepted academic practice. No use, distribution or reproduction is permitted which does not comply with these terms. 